\title{
ERRATUM
}

\section{FORUM: Forum on the State of the Field of Social Gospel Studies Editors' Note-ERRATUM}

doi: 10.1017/S0009640714001759, Published by Cambridge University Press, 5 March 2015.

The original publication of this article contained an error in the title. The correct title is "FORUM: Forum on the State of the Field of Social Gospel Studies"

The publisher regrets the error. The original article has been corrected to rectify this error.

\section{REFERENCE}

(2015). Forum on the State of the Field of Social Gospel Studies Editors' Note. Church History, 84, pp. 195. doi:10.1017/S0009640714001759 